\title{
ASSESSMENT OF PHYSICAL OCCUPATIONAL HEALTH HAZARDS IN SIDI KRIR
} POWER STATION

\author{
By \\ Abou Elmaati $\mathrm{A}^{1}$, Ismail $\mathrm{M}^{1}$, Hosny $\mathrm{G}^{2}$ \\ ${ }^{1}$ Department of Occupational Health, Safety, and Environment, Sidi kerir Power Station. \\ ${ }^{2}$ Professor of Public Health \& Occupational Medicine, Division of Environmental Health, \\ Department of Environmental Studies, Institute of Graduate Studies and Research, University of Alexandria.
}

\begin{abstract}
:
Introduction: Electrical industry is one of the main sources of exposure to physical hazards affecting environmental quality. Concern for a clean working environment for industrial workers is based on the fact that improved air quality leads to high productivity and human welfare for workers. This means that the efforts to improve the working environment have positive impacts on workers, concerned company, and the economy as a whole, and vice versa. Objective: to assess some of the environmental physical occupational health hazards: noise, heat stress and light intensity in Sidi Krir Power Station. Results: Result outcomes represented guides to contour maps of the potentially hazardous areas in the company for the selected physical hazards and to set up recommendations for corrective actions to improve and develop the performance of safety department. Conclusion and Recommendation: The current study concluded that environmental health and safety measures for physical occupational hazards among workers in Sidi Krir Power station can be managed and safely promoted, for better work environment.
\end{abstract}

Key words: Occupational health \& safety; Physical hazards, Sidi Krir, working environment. 


\section{Introduction}

Health, Safety and Environment (HSE) is a management responsibility which follows the Company's line organization in divisions and projects. HSE should be given the same priority as other work practices. It will be run in such a way that health and safety are promoted for all employees, a safe and beneficial working environment is provided, and the environment and property are protected (Hernandez, 2010).

Technological advances have created many environmental pollutants of which physical hazards as noise, radiation, heat stress and light intensity, have been identified (Knopper, 2011). Occupational exposure of workers takes place in an extremely complex array of physical, chemical, and biological agents, having impacts of an ergonomic, physiological and psychosocial nature. These impacts often threaten the safety and health of workers and reduce workers' productivity (Rosenblum \& Horvath, 2000).

Environmental pollution is one of the social problems which need awareness with the causative condition and protective equipments (Kaplan, 2001). Health impacts of physical hazards, e.g. noise, on workplace are now given more serious attention. Temporary or permanent hearing loss is the best-known health impact, although high noise levels are also known to be one of the critical stress factors that influence mental disorders and social pathologies (Pedersen \& Waye, 2007). The extent of noise responses is dependent on exegetic and androgenic moderator variables related to the characteristic of the particular individual, personal attribute and different stages of activity (Pedersen, 2009).

\section{Objective}

To assess some of the environmental physical occupational health hazards: noise, heat stress and light intensity in Sidi Krir Power Station and to set up recommendations for corrective actions for the company to improve and develop safe department.

\section{Materials \& Methods}

Research technical design: The underlying research has been performed on Sidi Krir Power Station aiming at evaluating and mapping the physical occupational health hazards

The case study: Because of the importance of applying rules targeting better achievement of health and safety, the present study was conducted in Sidi Krir Power Station that is located on the Mediterranean cost at distance about $29 \mathrm{~km}$ west of Alexandria. The company started its activity in 1999 by steam plant. It 
consists of two units; the capacity of each is 320 MW. It represents the most important company in producing electrical power in Alexandria. The company is operated by 1200 workers.

\section{Measuring levels of physical} hazards: Levels of noise, heat stress and light intensity were measured in different work places in the company, with different activities, to determine the levels of occupational exposure.

1. Noise. Noise was measured by using Sound Level Meter (Bruel \& Kjaer sound level meter, type 2250 and calibrator, type 4231). The technique is dependent on the transfer of sound energy to electrical energy and the energy is expressed in decibel $(\mathrm{dB})$. The noise type may be continuous noise (machinery and equipment), intermittent (hammers) or white noise (at the start of the steam boilers). The levels were analyzed and compared to documented permissible levels either nationally or internationally to set up a conclusion.

2. Heat Stress. It was measured by using Heat Stress Monitor. It was calculated by temperature radiation, the degree of wet thermometer and the degree of dry thermometer. Heat stress in workplace can be recognized by the human sense of heat and humidity, which together increase the sense of heat (Humidex). It was transferred by plug, convection currents and radiation. Results were compared to documented permissible levels to set up a conclusion.

3. Light. Light was measured by using Lux Meter. It depends on theory called photoelectric cell that can be transformed by the light falling on the cell to electric current which differs in severity depending on the intensity of the light falling on them. Light is a natural energy spread in all direction in straight lines in the form of waves that may be direct, semi direct or indirect. Levels of light were compared to documented permissible levels to set up a conclusion.

\section{Mapping of physical hazards within} the power plant.

Contour maps for the different levels of noise, heat stress, and light intensity during different months over year 2012 were set up to identify high risk locations.

Maps of the power plant were used to locate and identify high risk areas for the measured physical hazards in Sidi Krir Power Station. Maps identifying localizations of each hazard were performed. Thus, contour maps indicating high risk areas for noise, heat stress, and light intensity were yielded in Sidi Krir Power Station. 


\section{Results}

The current study was conducted in Sidi Krir Power Station to evaluate the levels of physical occupational health hazards including noise, heat stress, and light intensity and to map the high risky areas in the company for the selected hazards. The measurements were performed regularly each month for ten months, from February to November over year 2012 to evaluate risky areas in the company. Table (1) shows the measured levels of noise. The levels of noise varied from 72 to $92 \mathrm{~dB}$ in different compartments of the company. Figure (1) shows the average levels of noise over year 2012. The average levels varied from an upper limit of $89.8 \mathrm{~dB}$ to a lower limit of $75.8 \mathrm{~dB}$. A contour map for levels of noise in Sidi Krir Power Station over year 2012 was performed, as shown in Figure (2), to high light the risky levels in the company. Levels shown in dark (Figure 2) are presentations of hot spot levels. Figure (3) shows a contour map indicating the risky locations in the company for high levels of noise exposure, which are located mainly in Turbine units I and II, and Boiler units I and II. So attention should be given to ensure safety measures and minimize hazards.

Heat stress levels were measured regularly, as previously described., Table (2) shows the measured levels. The levels of heat stress varied from 24 to $31 \mathrm{oC}$ in different compartments of the company. Figure (4) illustrates the average levels of heat stress over year 2012. A contour map indicating levels of heat stress in Sidi Krir Power Station over the ten months is shown in Figure (5), denoting the risky areas in the company. Figure (6) shows a contour map indicating the risky locations in the company for high levels of heat stress, which are located mainly in Turbine units I and II, and Boiler units I and II.

Levels of light intensity were also monitored regularly during the study period, as previously described. Table (3) shows the measured levels. The levels of light intensity varied from 270 to 1770 Lux in different compartments of the company. Figure (7) shows the average levels of light intensity over year 2010. The levels varied from an upper limit of 1740.2 Lux to a lower limit of 280.1 Lux. A contour map for the levels of light intensity in Sidi Krir Power Station over year 2012 was performed, and plotted in Figure (8), to high light the risky locations. A contour map to allocate risky areas in the company for light intensity exposure is shown in Figure (9). Financial affairs, management affairs and store consumer were the highest in levels of light intensity. So attention should be given to ensure safety measures and minimize hazards. 
Table (1):The levels of Noise (dB) in Sidi Krir Power Station in different compartments.*

\begin{tabular}{|c|c|c|c|c|c|c|c|c|c|c|}
\hline The place & February & march & April & May & June & July & August & September & October & November \\
\hline $\begin{array}{l}\text { Turbine } \\
\text { unit I }\end{array}$ & 88 & 87 & 89 & 88 & 90 & 91 & 92 & 89 & 88 & 89 \\
\hline $\begin{array}{c}\text { Turbine } \\
\text { unit II }\end{array}$ & 89 & 88 & 87 & 89 & 91 & 92 & 90 & 88 & 89 & 90 \\
\hline Boiler unit I & 87 & 89 & 88 & 89 & 90 & 92 & 91 & 90 & 90 & 91 \\
\hline $\begin{array}{c}\text { Boiler unit } \\
\text { II }\end{array}$ & 89 & 87 & 88 & 89 & 90 & 91 & 92 & 91 & 90 & 91 \\
\hline Pump house & 86 & 88 & 88 & 89 & 89 & 90 & 89 & 88 & 87 & 88 \\
\hline $\begin{array}{c}\text { Metal } \\
\text { workshop }\end{array}$ & 82 & 84 & 85 & 87 & 88 & 89 & 88 & 87 & 86 & 87 \\
\hline $\begin{array}{l}\text { Carpentry } \\
\text { workshop }\end{array}$ & 74 & 76 & 75 & 76 & 78 & 80 & 79 & 78 & 77 & 79 \\
\hline $\begin{array}{l}\text { Electricity } \\
\text { workshop }\end{array}$ & 72 & 73 & 75 & 75 & 77 & 78 & 76 & 77 & 77 & 78 \\
\hline
\end{tabular}

* Noise was measured in decibel $(\mathrm{dB})$

Table (2): The levels of Heat Stress in Sidi Krir Power Station in different compartment.*

\begin{tabular}{|c|c|c|c|c|c|c|c|c|c|c|}
\hline The place & February & March & April & May & June & July & Augus & t September & October & November \\
\hline $\begin{array}{c}\text { Heater } \\
\text { Turbine I }\end{array}$ & 25 & 24 & 27 & 28 & 30 & 31 & 30 & 29 & 28 & 29 \\
\hline $\begin{array}{l}\text { Heater } \\
\text { Turbine II }\end{array}$ & 26 & 25 & 26 & 27 & 29 & 31 & 30 & 28 & 29 & 30 \\
\hline Turbine I & 26 & 27 & 25 & 26 & 28 & 30 & 29 & 30 & 28 & 29 \\
\hline Turbine II & 25 & 27 & 26 & 27 & 29 & 30 & 28 & 29 & 28 & 27 \\
\hline Boiler I & 27 & 28 & 28 & 29 & 28 & 30 & 29 & 30 & 29 & 30 \\
\hline Boiler II & 25 & 27 & 26 & 28 & 29 & 31 & 30 & 29 & 30 & 29 \\
\hline
\end{tabular}

* Heat stress was measured in centigrade $(\mathrm{oC})$. 
Abou Elmaati A et al.,

Table (3): The levels of light intensity in Sidi Krir Power Station in different compartments.*

\begin{tabular}{|c|c|c|c|c|c|c|c|c|c|c|}
\hline The place & February & March & April & May & June & July & August & September & October & November \\
\hline $\begin{array}{c}\text { Metal } \\
\text { Workshop }\end{array}$ & 450 & 470 & 460 & 480 & 490 & 490 & 480 & 470 & 460 & 470 \\
\hline $\begin{array}{l}\text { Carpentry } \\
\text { Workshop }\end{array}$ & 430 & 440 & 450 & 470 & 460 & 470 & 480 & 460 & 480 & 480 \\
\hline $\begin{array}{l}\text { Electricity } \\
\text { Workshop }\end{array}$ & 450 & 480 & 470 & 460 & 480 & 490 & 470 & 480 & 470 & 480 \\
\hline $\begin{array}{c}\text { Turning } \\
\text { Workshop }\end{array}$ & 420 & 430 & 430 & 440 & 460 & 470 & 460 & 470 & 460 & 470 \\
\hline $\begin{array}{c}\text { Instrumental } \\
\text { Workshop }\end{array}$ & 500 & 520 & 510 & 520 & 500 & 520 & 510 & 500 & 510 & 500 \\
\hline Pump House & 400 & 410 & 420 & 440 & 430 & 440 & 430 & 420 & 430 & 420 \\
\hline Fire Pumps & 280 & 270 & 290 & 280 & 270 & 300 & 290 & 280 & 290 & 270 \\
\hline $\begin{array}{c}\text { Store } \\
\text { Consumer }\end{array}$ & 500 & 520 & 530 & 520 & 510 & 530 & 520 & 510 & 500 & 510 \\
\hline Store Parts & 530 & 510 & 520 & 530 & 540 & 540 & 530 & 520 & 510 & 520 \\
\hline $\begin{array}{c}\text { Control } \\
\text { Room }\end{array}$ & 900 & 920 & 900 & 910 & 920 & 930 & 910 & 900 & 910 & 900 \\
\hline $\begin{array}{c}\text { Financial } \\
\text { Affairs }\end{array}$ & 1700 & 1730 & 1720 & 1740 & 1760 & 1770 & 1750 & 1760 & 1740 & 1750 \\
\hline $\begin{array}{c}\text { Management } \\
\text { Affairs }\end{array}$ & 1390 & 1380 & 1390 & 1370 & 1390 & 1400 & 1380 & 1370 & 1380 & 1370 \\
\hline $\begin{array}{l}\text { Treatment } \\
\text { Unit }\end{array}$ & 350 & 370 & 360 & 370 & 390 & 400 & 380 & 390 & 380 & 390 \\
\hline
\end{tabular}

* Light intensity was measured in Lux. 


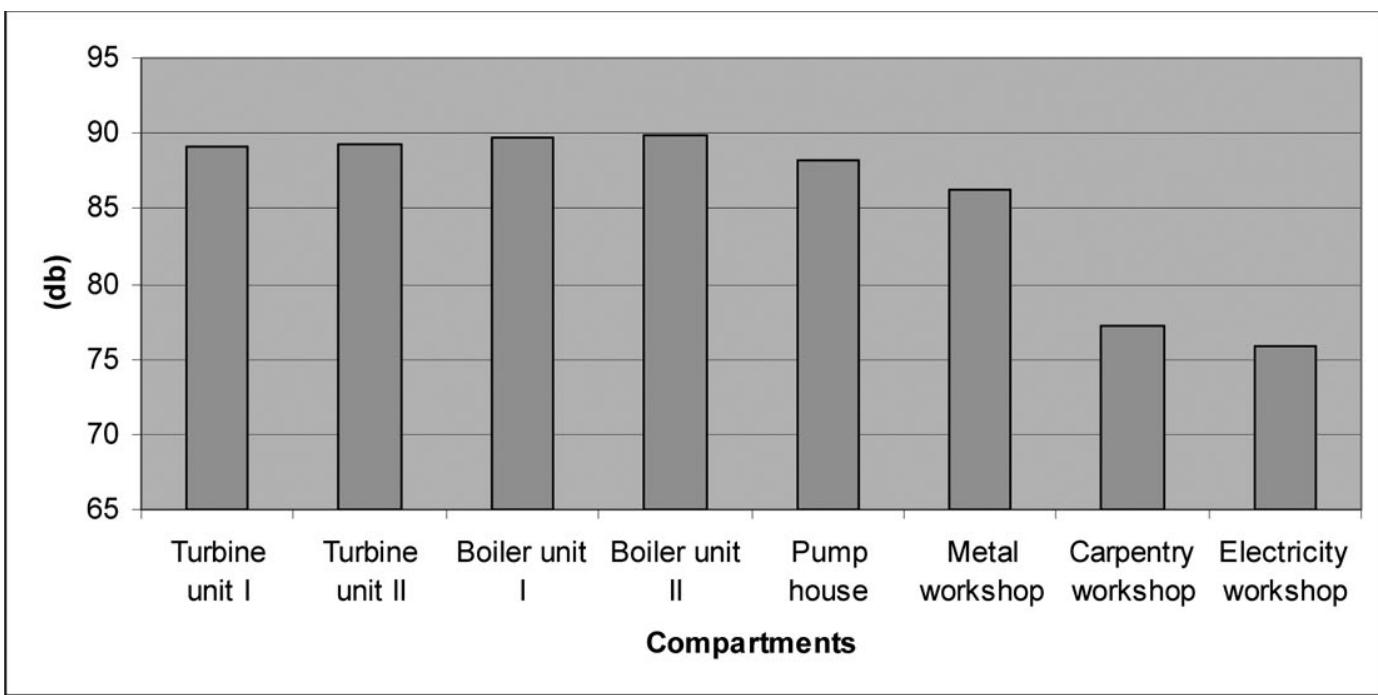

Figure (1): Average levels of Noise (dB) in different compartments in Sidi Krir power station.

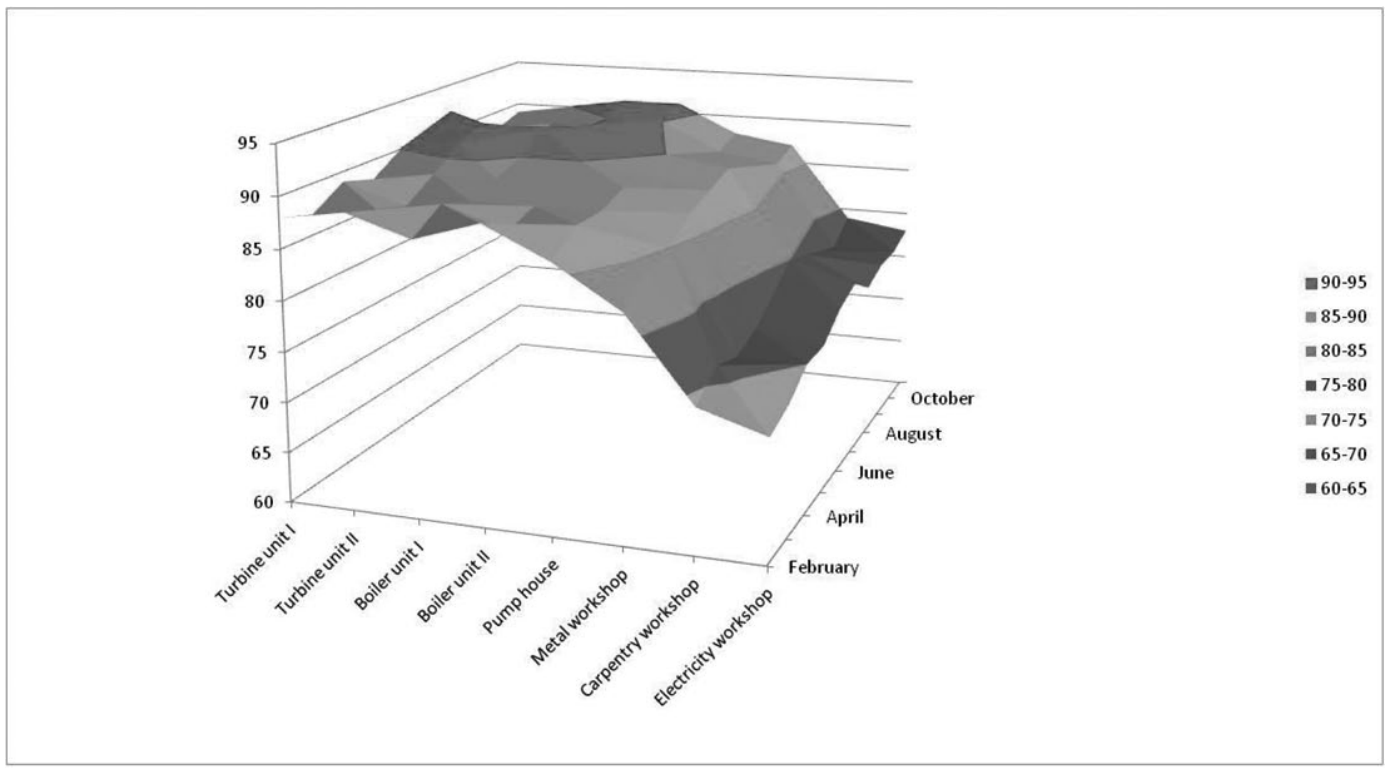

Figure (2): A Contour map for levels of noise (dB) in Sidi Krir Power Station over year 2012. 


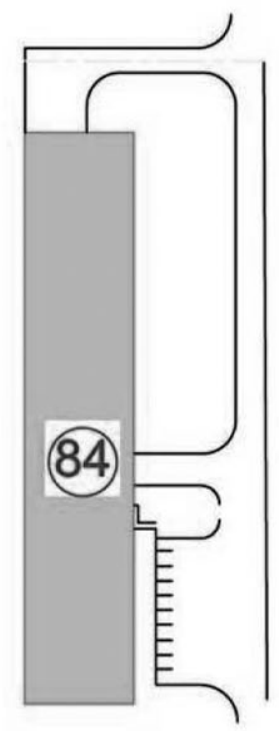

(11) Boiler building unit 1

(12) Boiler building unit 2

(21)Turbine building unit 1

(22) Turbine building unit 2

(55) Hypo-chlorite building

(84) Maintenance Shop

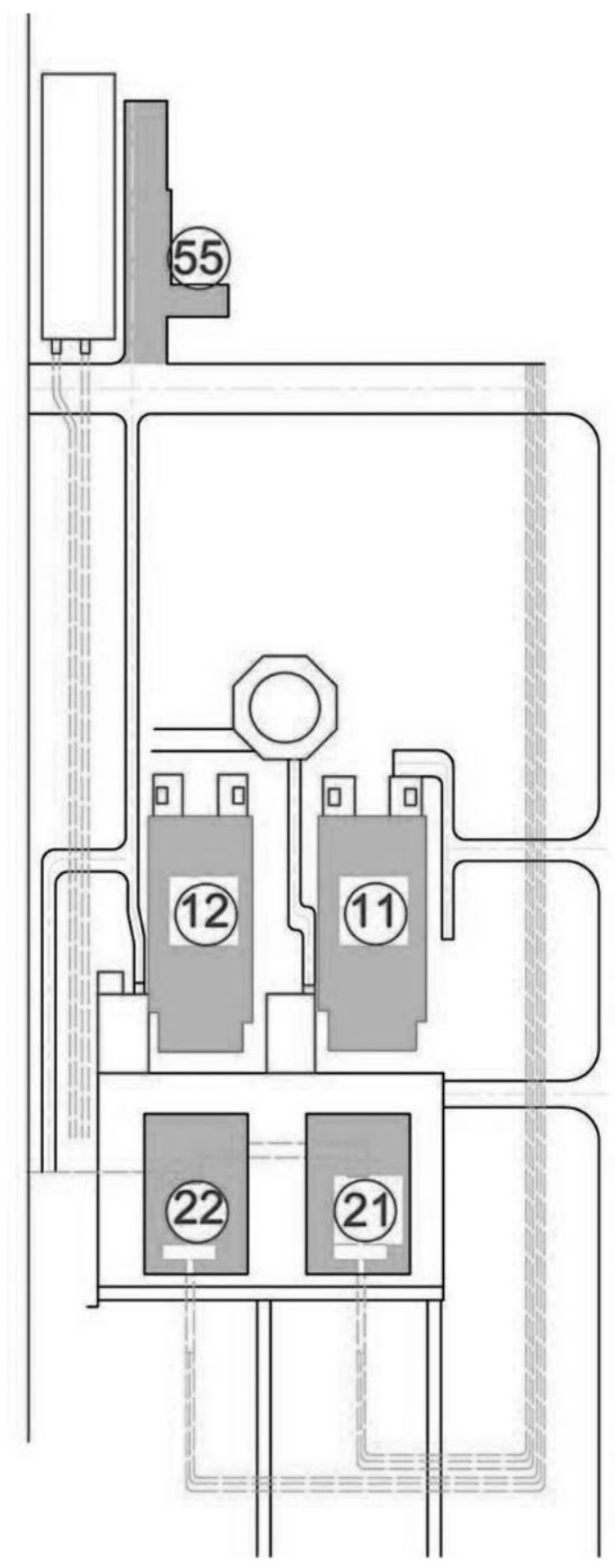

Figure 3: A Contour map indicating high risky locations for noise levels in Sidi Krir Power Station. 


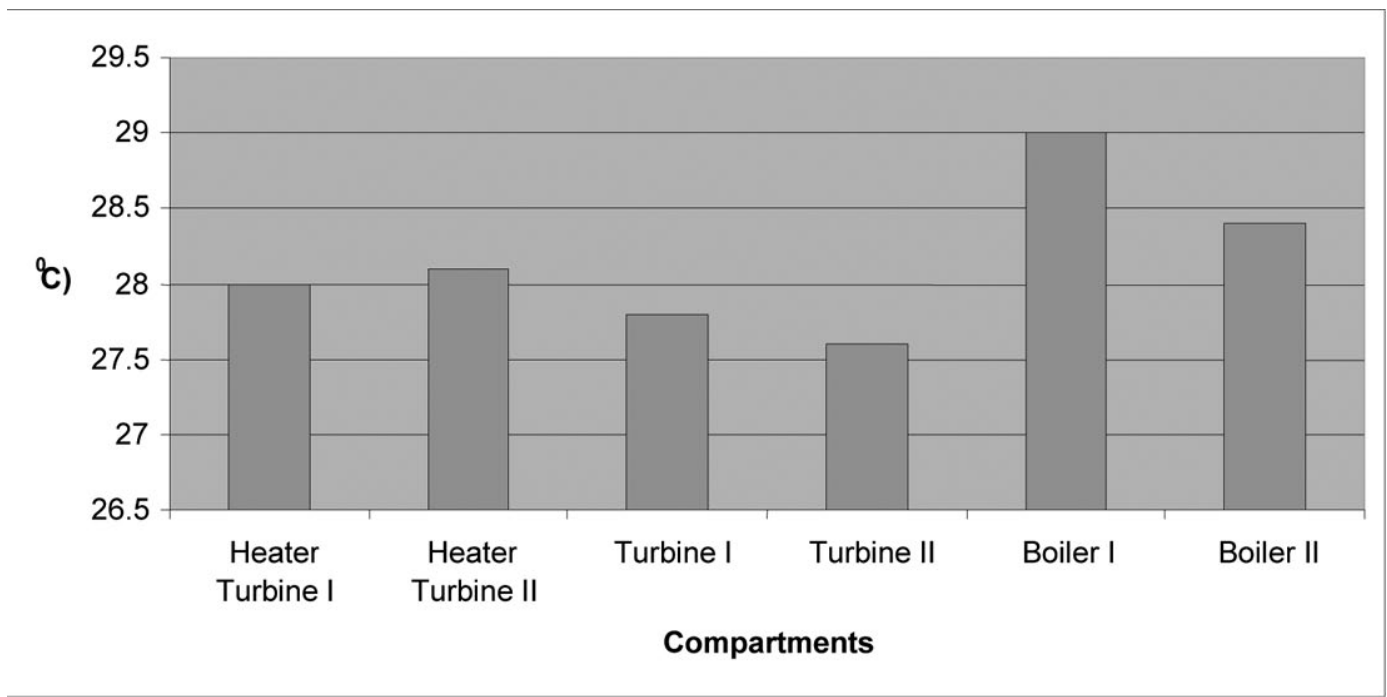

Figure (4): Annual average levels of Heat Stress (oC) in Sidi Krir Power Station in different compartments.

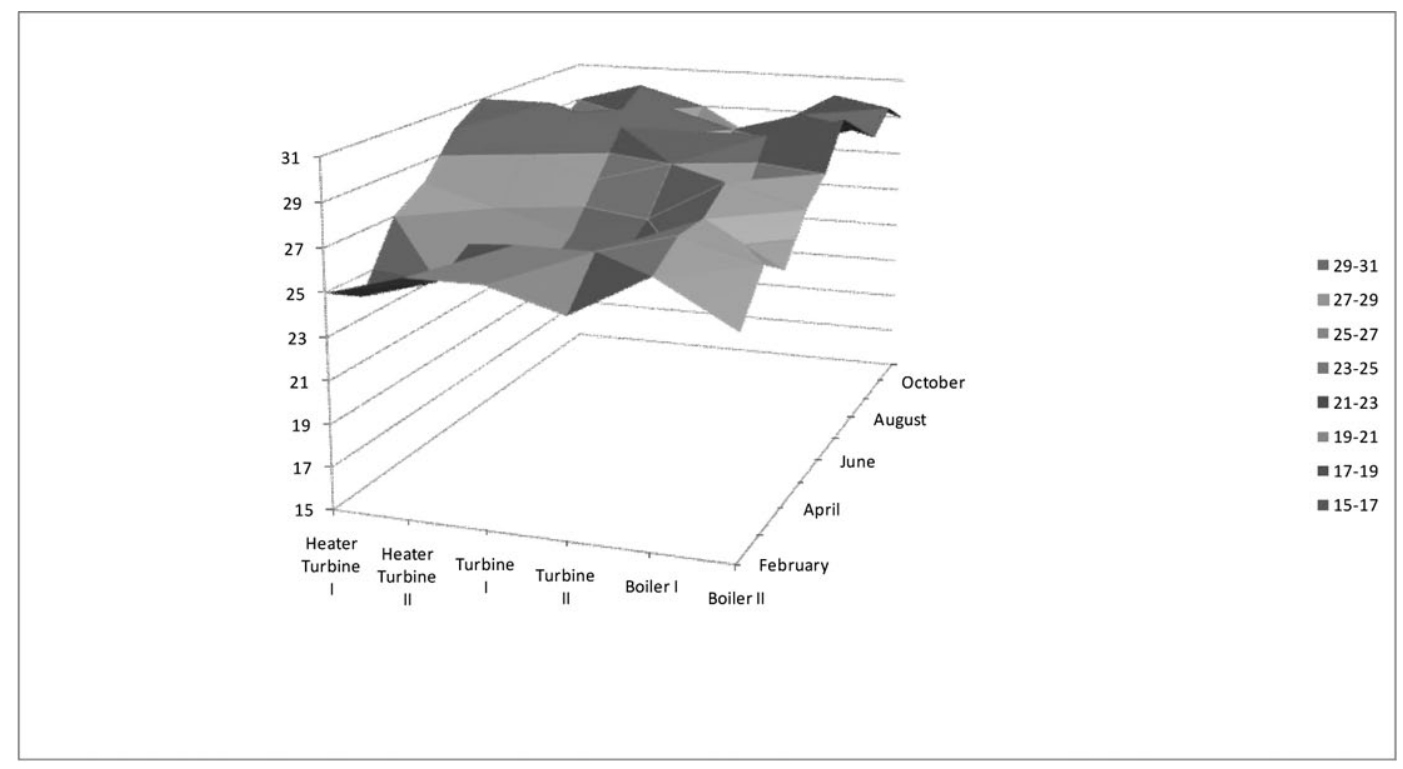

Figure (5): A Contour map for levels of heat stress $\left({ }^{\circ} \mathrm{C}\right)$ in Sidi Krir Power Station over year 2012. 


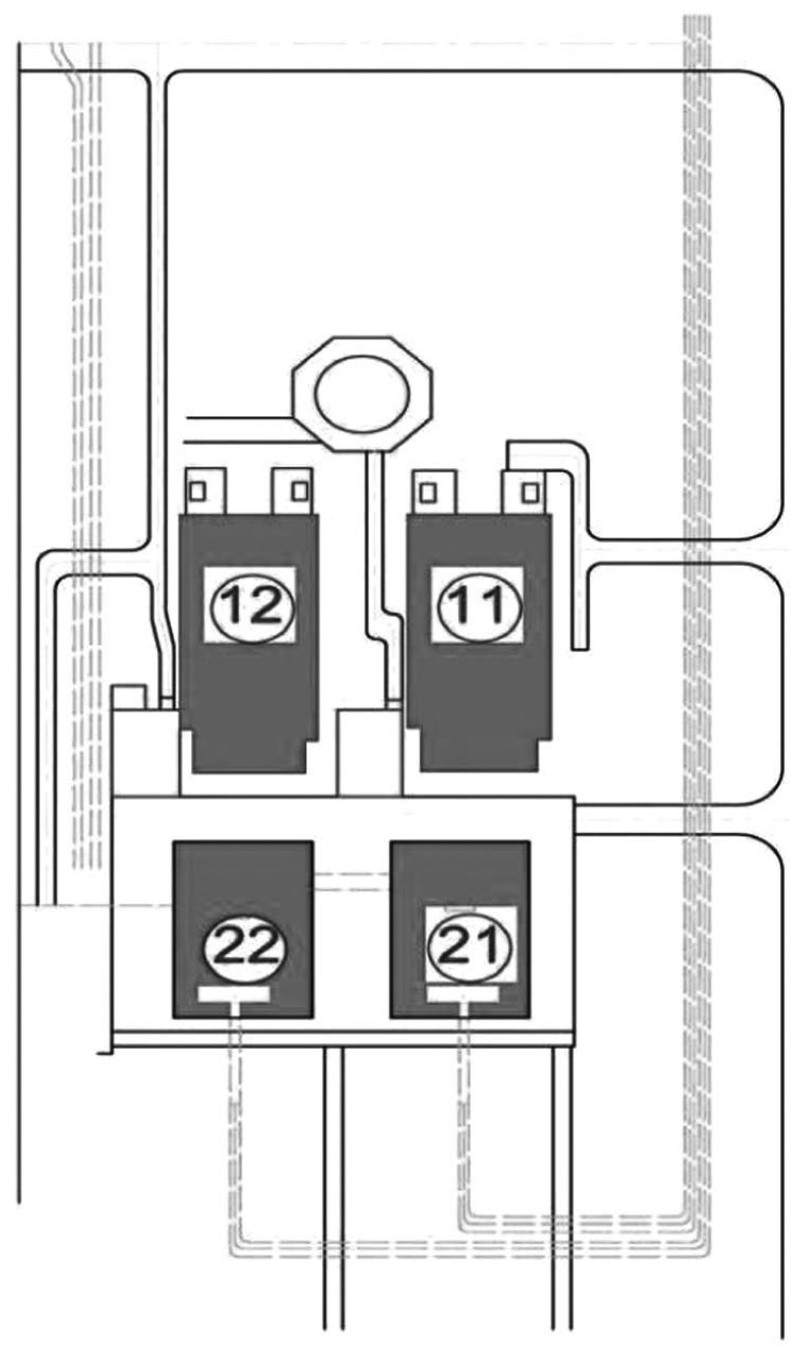

\section{1) Boiler building unit 1 \\ (12) Boiler building unit 2 \\ 21) Turbine building unit 1 \\ 22) Turbine building unit 2}

Figure 6: A Contour map indicating high risky locations for heat stress in Sidi Krir Power Station. 


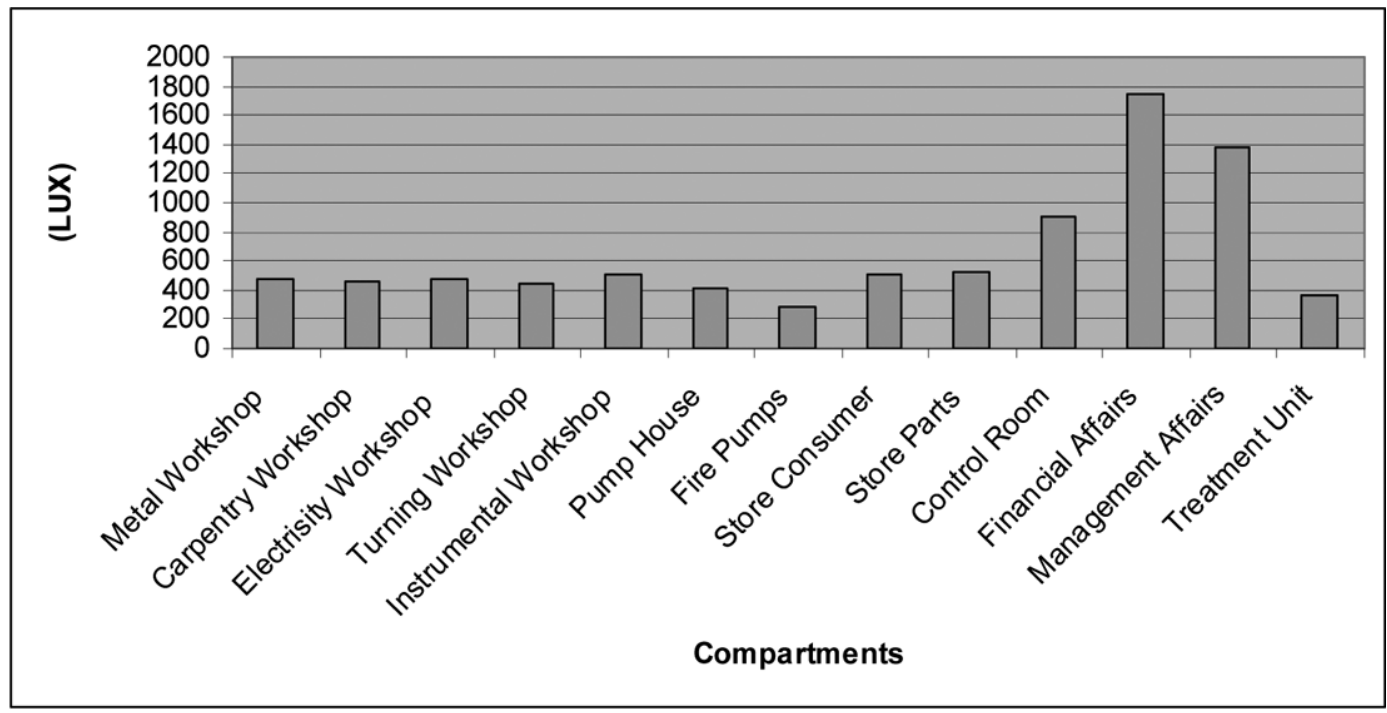

Figure (7): Annual average levels of light intensity (Lux) in Sidi Krir Power Station in different compartments.

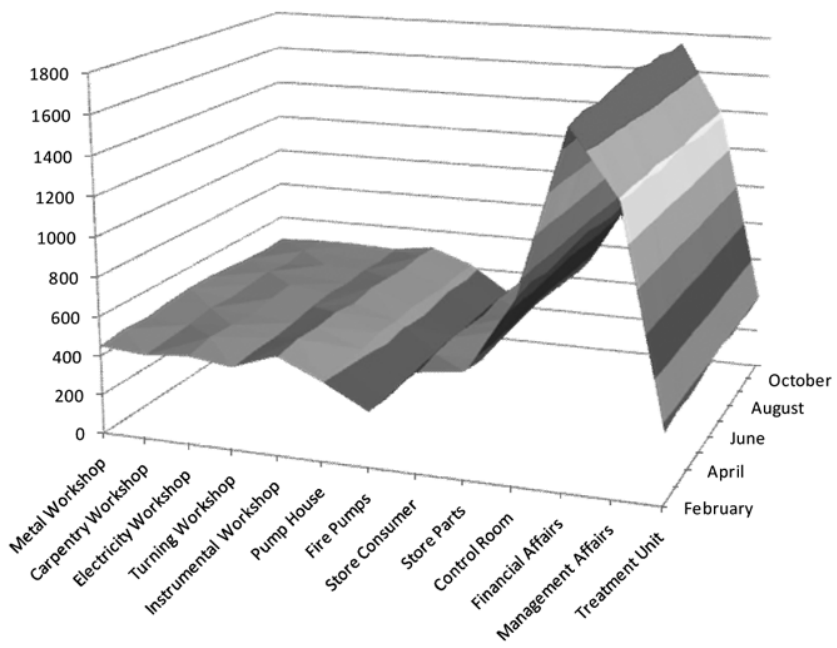

=1600-1800

$=1400-1600$

$=1200-1400$

1000-1200

= 800-1000

= $600-800$

= 400-600

= 200-400

$0-200$

Figure (8): A Contour map for levels of Light intensity (Lux) in Sidi Krir Power Station over year 2012. 


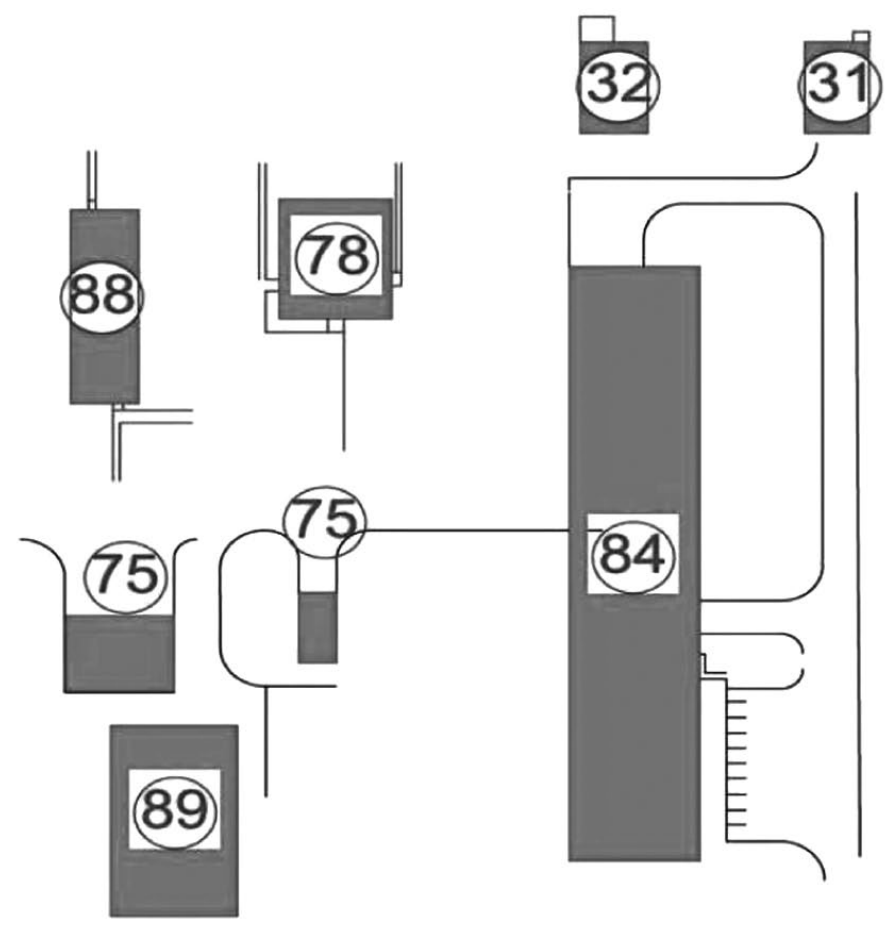

(31) Control building 1

(32) Control building 2

(75) Fire Water Pump House

(78) Water Treatment building

(84) Maintenance Shop

(88) Construction Manager Office building

(89) Garage and Vehicle shop

Figure 9: A Contour map indicating high risky locations for light intensity in Sidi Krir Power Station 


\section{Discussion}

The current study was undertaken aiming at assessing the levels of physical hazards; which are noise, heat stress, and lightintensity,inSidiKrirPowerStation.Our study results shows that the measured noise levels varied from 72 to $92 \mathrm{~dB}$ in different compartments of the company, indicating that protective measures should be applied for noise exposure. Comparing the results of the current study with permissible levels documented by Occupational Safety and Health Administrations (OSHA, 1995) and by Egyptian Environmental Law (EEL), $9 / 2009$, it is clear that the power station has some risky levels for noise that exceed the permissible levels for eight hour working period/day. The risky locations were shown to be in the turbine unit II ( $92 \mathrm{~dB})$ and boiler unit II $(92 \mathrm{~dB})$. So protective measures should be taken to control exposure to the risky levels of noise and its health impacts by: substitution of high noise equipments; good maintenance to equipments; application of sound reduction materials; regulation of exposure time among workers according to laws; and ensure use of personal protective equipments. The health impacts of noise on workplace are now given more serious attention. Temporary or permanent hearing loss is the best-known health impact, although high noise levels are also known to be one of the critical stress factors that influence mental disorders and social pathologies (Pedersen \&Waye 2007, Pedersen 2009).

Levels of heat stress were calculated over year 2010, with an upper limit of 31 $\mathrm{oC}$ to a lower limit of $24 \mathrm{oC}$, indicating that protective measures for heat stress exposure should be applied. Comparing the results of the current study with the permissible levels documented by Egyptian Environmental Law, 9/2009 and OSHA, 1993, it is clear that the power station has some risky levels for heat stress in medium work and exposure time (4-6 hours), in heater turbine unit I $(31 \mathrm{oC})$ and boiler unit II $(31 \mathrm{oC})$. So cautions should be taken to control exposure to these levels of heat stress to reduce its health impacts as it was documented (Raleigh, 2001). If any worker is exposed for a period of one continuous or intermittent hour during two working hours to working conditions of extreme temperature in excess of 26.18 centigrade for men and 24.58 centigrade for women, one or more of the following methods shall be used to ensure that the worker's internal temperature does not rise above 38 centigrade: 
(A) Acclimatizing the worker to the temperature over a period of six days by exposing him/her to $5 \%$ of the daily exposure period on the first working day then increasing the period of exposure by $10 \%$ a day until it reaches $100 \%$ on the sixth day.

(B) A worker who absents himself for a period of nine days or more after the acclimatization process or who falls ill for a period of four consecutive days must be reacclimatized over a period of four days by being exposed to $50 \%$ of the daily exposure period on the first day and an additional $20 \%$ a day thereafter so as to reach $100 \%$ exposure on the fourth day (Raleigh, 2001). Heat stress is caused by a combination of environmental, work, and clothing factors and tends to increase body temperature, heart rate, sweating, lowering blood pressure and fainting. These physiological adaptations are collectively known as heat strain or heat stress. Heat stress in workplace can be recognized by the human sense of heat and humidity together, Humidex (Wenzel, 1987). Effect of exposure to high levels of heat stress can be controlled by working under precautionary supervision and being slotted into coolest periods of the day; organizing working hours to reduce the physiological stress and enable worker to get adequate rest between working hours to enable him to drink a saline solution; and providing and using suitable protective clothing, engineering control and equipment (Raleigh, 2001).

Levels of light intensity in our study, varied from 270 to $1770 \mathrm{Lux}$ in different compartments of the company. Comparing the results of the current study with permissible levels documented by FEMP, 2010 , it is clear that the power station has some risky levels for light intensity (Table 3) in financial affairs (1770 Lux) and management affairs (1400 Lux). The levels of light intensity should be controlled to provide proper lighting for the type of work practiced and to avoid adverse health effects on workers' eyes. Whether natural or artificial lighting, it should be in homogenous distribution in the workplace (IESNA, 2007).

The results of the current study guided to contour risky high level exposure locations for noise, heat stress and light intensity in maps for the power plant to help the decision makers in Sidi Krir Power Station to set plans for optimizing the performance of health and safety.

It was found that high level risk areas for exposure to noise in Sidi Krir Power Station are boiler building unit 1 , boiler 
building unit 2 , turbine building unit 1 , turbine building unit 2, hypo-chlorite building and maintenance shop.

Also, risky locations for the high level exposure to heat stress in Sidi Krir Power Station were set to be building unit 1 , boiler building unit 2 , turbine building unit 1and turbine building unit 2 .

While that for light intensity were control building 1 , control building 2, fire water pump house, water treatment building, maintenance shop, construction manager office building, garage and vehicle shop.

\section{Conclusion}

The current study concluded that environmental health and safety measures for physical occupational hazards among workers in Sidi Krir Power station can be managed and safely promoted, for better work environment.

\section{References}

1. Egyptian Environmental Law (EEL) 9/2009: Maximum permissible levels inside places of productive activities.

2. FEMP (2010): Federal Energy Management Program: Lighting Control Types. Retrieved Apr. 2011, available on http://wwwl.eere. energy.gov/femp/technologies/eep_light_ controls.html
3. Hernandez AB, Martin AM, Ruiz $\mathrm{C}$ and Hidalgo $C$ (2010): The role of place identity and place attachment in environmental protection laws. Environmental Psychology; 30: 281-288. IESNA - Office Lighting Guide 2007.

4. Kaplan BS (2001): The restorative benefits of nature: Toward an integrative framework. Environmental Psychology; 15: 169-182.

5. Knopper LD and Ollson CA (2011): Health effects and turbines noise pollution: a review of the literature. Environmental Health; 10: 78.

6. Occupational safety and health administrations (OSHA) (1993): Consult the AGGIH. Table III: 4-2. Permissible heat exposure in the work.

7. Occupational safety and health administrations (OSHA) (1995): CFR 29, standard number: 1910.95. Table G-16-Permissible noise exposures.

8. Pedersen E and Waye KP (2007): Thermal turbine noise, annoyance and self-reported health and well-being in different living environment; 64 : 480-486.

9. Pedersen E (2009): Effects of wind turbine noise on humans. In: Third international meeting on turbine noise, Aalborg, Denmark; 17-19.

10. Raleigh, N.C (2001): A guide to preventing heat stress. Department of labor: Occupational Safety and Health Division N.C- U.S.

11. Rosenblum GJ and Horvath A (2000): Environmental implications of services industries. Environmental Science; 34 (22): 4669-4676.

12. Wenzel L (1987): Heat stress upon undressed man due to different combinations of elevated environmental temperature, air humidity and metabolic heat production: a critical comparison of heat stress indices; 7: 185-206. 